\title{
The Impact of Country of Origin on Relationship Quality: Empirical Evidence from Automotive Industry
}

\author{
Haim Hilman \\ Jalal Hanaysha \\ College of Business, Universiti Utara Malaysia \\ Email: jalal.hanayshi@yahoo.com
}

Doi:10.5901/mjss.2015.v6n2p165

\begin{abstract}
This study examines the impact of country of origin on relationship quality in automotive sector. Four hypotheses were developed to test the relationships between country of origin and relationship quality. Relationship quality in this research is composed of three elements; brand trust, brand commitment, and brand satisfaction. Data were collected using survey questionnaire from 287 respondents of passenger car users in Northern region of Malaysia. To test the conceptual framework, Structural Equation Modelling (SEM) using AMOS 18 was employed as data analysis technique. In general, the SEM analysis revealed that country of origin has a significant positive influence on overall relationship quality. Moreover, the analysis indicated that country of origin has significant positive influence on brand trust, brand commitment, and brand satisfaction. Based on the findings of this study, it is suggested to the strategic policy makers in the automotive sector to emphasize on these three basic determinants of relationship quality; brand trust, brand commitment, and brand satisfaction to cope with intense competition. Particularly, this study would guide automotive manufacturers to benefits from these findings to enhance customer relationships through utilizing positive country of origin image.
\end{abstract}

Keywords: Brand commitment; brand satisfaction; brand trust; country of origin; relationship quality

\section{Introduction}

Today's business is becoming highly competitive and challenging. As such, continuous improvement of reciprocal long term relationship strategy with customers has been one of the main priorities for several organizations. Previous studies have shown that a high quality of customer relationships can improve customer commitment and is necessary for business success (Hilman, Abd-Ghani, \& Hanaysha, 2013). Such a relationship would decrease ambiguity for customers and facilitate the process of maintaining a superior business relationship (Abdullah, Putit, \& Teo, 2014). According to Ali (2010), keeping a good relationship with customers is crucial for the success of business, because it can increase customer retention rates. Therefore, the relationship paradigm should be directed towards emphasizing on the mechanisms that enable organizations to enhance their quality of relationships with customers in order to get shared benefits of concerned parties (Ndubisi, 2007).

The notion of relationship quality arises from the theory and research in the area of relationship marketing in which it primarily aims to strengthen existing powerful relationships and to enhance customer loyalty (Chung \& Shin, 2010; Rauyruen and Miller, 2007). Successful relationship marketing also grants brands with sustainable competitive advantages (Anderson and Narus, 1990; Roberts, Varki and Brodie, 2003). According to Ford (1980), high quality of relationships between organizations and their customers connect both parties to each other in a manner that they are capable to obtain advantages beyond the mere exchange of products. This as a result would lead to long-lasting and consistent relationships in which both parties equally benefit and gain useful experience (Sean, Brian, \& Evelyn, 2004).

Halimi, Chavosh, and Choshali (2011) advocated that organizations should manage customer relationship strategies by bearing in mind important factors that influence their relationships in order to successfully create beneficial customer- brand relationships and generate higher profit margins. For instance, certain scholars (Michaelis, Woisetschläger, Backhaus, \& Ahlert, 2008; Tam, 2008) considered country-of-origin as one of the important factors that influence customers' behaviour and guide firms toward maintaining valuable relationships with them. Similarly, Jiménez and Martín (2012) emphasized that country of origin information works as a safeguard transaction to build superior brand relationships. Particularly, the reputation of brands originating from a certain country becomes a key measure of available offer and also a basis in establishing trust-based relationships over time (Jiménez \& Martín, 2012; Nijssen \& Herk, 2009). 
This study examines the effect of country of origin on relationship quality in Malaysian automotive market. Based on the review of past research, it shows that are limited research works which examined the role of country of origin in affecting relationship quality and its dimensions (Michaelis et al., 2008). Particularly, there exists a gap in past studies with regards to empirical research on country of origin and relationship quality. Therefore, this study is planned to establish empirical evidence on the effect of country of origin on relationship quality in Malaysian automotive market. Undoubtedly, the automotive industry in Malaysia plays a vital role in the improvement of Malaysian manufacturing sector and it contributes significantly to the economic development of the country (Kari \& Rasiah, 2008). Hence, this study through its findings and recommendations is expected to provide beneficial suggestions to automotive manufacturers to learn developing better customer-brand relationships.

\section{Literature Review}

This section reviews the prior research on relationship quality and country of origin with various definitions and empirical evidence between both constructs.

\subsection{Relationship Quality}

Relationship quality is one of the main concepts of relationship marketing (Ural, 2007), which can be determined through the overall judgment of customers towards their relationship strength with a brand. In other words, relationship quality refers to customers' perception of relationship outcomes in terms of fulfilling their expectations and desires (Wong \& Sohal, 2002). Roberts et al. (2003) defined relationship quality as "a measure of the extent to which consumers want to maintain relationships with their service providers" (p. 191). Therefore, it can be suggested from the above definitions that relationship quality is concerned with overall nature of the relationship between a brand and its customers taking into account the extent of fulfilling the needs and expectations in determining relationship success (Hennig-Thurau, Langer, \& Hansen, 2002).

Relationship quality was previously conceptualized as a higher-order construct which is comprised of several dimensions or components (Dorsch, Swanson, \& Kelly, 1998). Although there exists a bulky discussion on which dimensions make up relationship quality, earlier research mainly emphasized on the importance of brand satisfaction, brand trust, and brand commitment as key indicators of relationship quality (Hilman, Abd-Ghani, \& Hanaysha, 2013). These three components have been widely cited by several scholars as core elements of relationship quality (Vieira, Winklhofer, \& Ennew, 2008; Walter, Muller, Helfert, \& Ritter, 2003; Ulaga \& Eggert 2006; Ivens and Pardo 2007; Crosby, Evans \& Cowles, 1990).

For example, certain scholars (Crosby et al., 1990; Dwyer, Schurr, \& Oh, 1987) used relationship satisfaction and trust to measure relationship quality. Other views (Hennig-Thurau and Klee, 1997; Dorsch et al., 1998) further suggested including relationship commitment into relationship quality dimensions. Similarly, Hibbard, Kumar, and Stern (2001) believed that relationship quality is made of up of brand trust and brand commitment. Furthermore, De Wulf, OdekenSchroder, and lacabucci (2001) regarded relationship quality as a construct that includes brand satisfaction, brand trust, and brand commitment. Therefore, based on the discussion made above, we believe that superior-quality relationship is composed of trust, commitment, and satisfaction.

Trust is one of the most broadly tested and established constructs in the field of relationship marketing research (Crosby et al., 1990, Garbarino \& Johnson 1999, Moorman, Zaltman \& Despandé 1992, Morgan \& Hunt 1994). Zhang and Feng (2009) suggested that customer trust plays an important role in establishing long term brand relationship and reaching to customer loyalty. As argued by Mukherjee and Nath (2007), trust is very critical to relational exchange because it is the main elements in any strategic partnership between members. Huang and Chiu (2006) further added that increased trust is necessary for relationship success between organizations and their customers. According to Morgan and Hunt (1994), relationships can be viewed as a set of dealings that promote an awareness of a pooled relationship through brand trust and brand commitment. Therefore, higher levels of trust could result in superior organisational profitability and sustainable competitive advantage (Van Vuuren, Roberts-Lombard, \& Van Tonder, 2013).

The significance of commitment in relationship marketing paradigm appears to be evidently established in the past literature (Barry, Dion \& Johnson, 2008; Hilman et al., 2013; Hsu, Chen \& Huang, 2007). This is because committed customers are the foundation of business continuity and exert enhanced future values and profits for organizations (Lemon, Rust, \& Zeithaml, 2001). Relationship commitment was described by Gounaris (2005) as the willingness of customers to continue to invest resources in a relationship with business provider. In other words, commitment is a sort of intention to create and sustain a long-term brand relationship (Anderson \& Weitz 1992, Dwyer, Schurr \& Oh 1987, 
Moorman, Zaltman \& Despandé 1993). According to Morgan and Hunt (1994), commitment stems from trust, shared values, and the belief that it will be difficult to find partners that can offer the same value. Ibrahim and Najjar $(2008,14)$ revealed that "relationships are built on the foundation of mutual commitment, and the commitment level has been found to be the strongest predictor of the voluntary decision to pursue a relationship".

Similarly, relationship satisfaction has been considered to be important for relationship success. This is because satisfied customers are more likely to make repeat purchases and be willing to spread positive messages through word of mouth communication according to their experiences (Taylor, 1998; Bennett \& Rundle-Thiele, 2004; Schultz, 2005). Customer satisfaction is determined through firms' ability to fulfil the needs and desires of customers through differentiated offerings (Spreng, MacKenzie, \& Olshavsky, 1996). Anderson et al. (1994) viewed relationship satisfaction as an overall evaluation based on the past purchase and experience. Roberts-Lombard $(2009,73)$ defined customer satisfaction as "the degree to which a business's product or service performance matches up to the expectation of the customer. If the performance matches or exceeds the expectations, then the customer is satisfied, if performance is below par then the customer is dissatisfied".

\subsection{Country of Origin}

Country-of-origin is one of the most important factors that significantly influence purchasing decision of consumers. It was expressed by Saydan (2013) as encompassing the subjective perceptions of customers about certain aspects related to a product brand such as the belief, ideas, and impressions before forming purchasing decisions. Country of origin was also described by Piron (2000) as the country where corporate headquarters of the firm marketing the product or brand is located. In other words, it refers to the country that manufactures, designs, or assembles a product (Essoussi and Merunka 2007). Therefore, the country of origin "made in label" plays an important role in consumer's decision making and in today's competitive and global market environment which helps firms in increasing product sales (Saydan, 2013).

In the current business scenario which is characterized by intense competition and increasing number of brands, country of origin image has become an important evaluation criterion for selecting a particular brand among others. A well established reputation indeed has positive impact on consumers' preference for purchasing products of certain brands and increases the perceived reliability of a firm because it offers a safeguard that promises and obligations will be fulfilled (Bennett \& Gabriel, 2001; Doney \& Cannon, 1997; O'Cass \& Grace, 2003). According to Roth and Romeo (1992), a country's image arises from a series of aspects that empower the image of a country. Such aspects include innovative approach (superior, cutting edge technology); design (style, elegance, balance); and prestige (exclusiveness, status of the national manufacturers).

Meanwhile, country image is established through consumer's understanding about a certain country through benefits and experiences perceived about that country in the past (Rezvani, Shenyari, Dehkordi, Salehi, Nahid, \& Soleimani, 2012). For example, country of origin image can be highly affected by product quality of a certain brand category from particular country (Lin and Chen, 2006). In making a decision to purchase a product, the effect of country of origin appears from the past experience and knowledge that customers perceive about a particular country (Rezvani et al., 2012). Therefore it can either make a product more or less appealing in the mind of the customers. According to Tam (2008), country of origin is one of the important factors in evaluating a foreign product that affect consumer's behaviour such as trust. Jiménez and San Martín (2010) added that brand trust can be developed by the positive perception of country of origin.

Previous studies revealed that signals of product quality related to country of origin have significant impact on relationship quality elements (Jiménez \& San Martín 2009; Steenkamp \& Geyskens, 2006). As specified by Jiménez and San Martín (2009), country of origin influences customers' behaviour towards building relationship trust and it guides firms towards engendering better brand management. They indicated that as trust depends on the country-of-origin of a brand, therefore, firms should frequently provide different incentives that would ultimately lead to the maintenance of customer's perception toward brand reliability in international markets. Singh and Sirdeshmukh (2000) further considered brand trust as a consequence of the reputation of firms associated with country of origin, because this reputation can be a significant determinant of quality, particularly, when customers would believe that foreign firms will deliver their responsibilities, promises and whatever else is expected of them as desired (Singh \& Sirdeshmukh, 2000).

The reputation associated with country of origin can be transferred across different brands originating from the same country, thus enhancing the reliability of sellers (Chisik, 2003; Doney \& Cannon, 1997; Ganesan, 1994), and increasing the level of customer satisfaction resulting from the purchase decision. Kim (1995) assumed that a positive country image would lead to favourable brand popularity, and consequently enhances brand commitment and loyalty. It was also demonstrated by certain scholars (Paswan et al, 2003; Pappu, Quester, \& Cooksey, 2006) that customer loyalty 
towards brands originating from favourable country image could develop according to their experience of certain brands that provide quality products. Based on the discussion made above, the following hypotheses are presented:

$\mathrm{H1}$ : Country of origin has positive effect on brand trust.

$\mathrm{H} 2$ : Country of origin has positive effect on brand commitment.

H3: Country of origin has positive effect on brand satisfaction.

$\mathrm{H} 4$ : Country of origin has positive effect on overall relationship quality.

\section{Research Methodology}

This study is based on primary data whereby a questionnaire was employed for data collection. The quantitative approached is employed because measurable and observable data on variables can be easily collected (Creswell, 2012). Moreover, quantitative research is best suited to understand how one or more variables affect each other (Creswell (2012). The designed questionnaire was distributed to passenger car users with some instructions of how to fill it at several shopping malls in Northern region of Malaysia. A sample size of 384 passenger car users is considered to be sufficient according to the suggestions and recommendations of Krejcie and Morgan (1970). According to Lei and Lomax (2005), this number of sample is sufficient for conducting analysis suing structural equation modelling. In order to ensure randomization of data collection, systematic sampling technique is used whereby every $10^{\text {th }}$ leaving customer at the entrance of shopping malls was approached to participate in filling the questionnaire. Total 287 usable questionnaires are returned from respondents and used for data analysis. Incomplete questionnaires were deleted and not included in data analysis

Since this study aims to examine the relationship between country of origin and relationship quality, thus, the constructs were measured using items adapted from several previous research works in the related field. Meanwhile, relationship quality is measured using three dimensions; brand trust, brand commitment, and brand satisfaction. Five items for country of origin are adapted from Sanyal and Datta (2011), five items for brand trust are adapted from Mohammad (2012), four items for brand commitment are adapted from Ok, Choi, and Hyun (2011), and five items for brand satisfaction are adapted from Zboja and Voorhees (2006).

All the questionnaire items are measured on seven-point Likert scale, ranging from 1 (strongly disagrees) to 7 (strongly agree). For the ease of understanding, the questionnaire was translated into Malay language. The data were analyzed using structural equation modelling (AMOS-18). At first, the measurement model was drawn to conduct confirmatory factor analysis (CFA) and then, the structural equation modelling was drawn with several goodness of fit criterion to test the hypothesized relationships. Previous research established SEM as a powerful statistical method which combines confirmatory factor analysis (CFA) and structural model into a consecutive statistical test (Gunzler, Chen, Wu, \& Zhang, 2013; Hoe, 2008). It allows the researcher to easily assess how sets of observed variables represent constructs and how these constructs associate with each other (Hair et al., 2010). Moreover, SEM is flexibile in modeling the relationships between multiple predictor and criterion variables (Chin, 1998). In most cases, SEM is applied to examine 'causal' relationships between variables making it clear to articulate the hypothesis (Gunzler et al., 2013). Specifically, it allows the researcher to easily assess how sets of observed variables represent constructs and how these constructs associate with each other.

\section{Analysis of Results}

The descriptive statistics showed that out of $287,47.4 \%$ were male where as $52.6 \%$ were female. On respondent's age, $12.5 \%$ represent age group of less than 25 years, $48.8 \%$ represented the age group of $25-35,16 \%$ represented age group of $35-45$ and $22.6 \%$ represented 45 and above age group. On religion, $75.3 \%$ of respondents are Muslims, $14.6 \%$ are Buddhists, $4.5 \%$ are Hindu, $4.9 \%$ are Christians, whereas $0.7 \%$ belong to other religions. On educational level, $43.2 \%$ had high school certificate, $21.6 \%$ had diploma, $25.4 \%$ belong to bachelor's level, $5.2 \%$ had master degree, $2.8 \%$ had doctorate certificate, while 1.7 had other certificates. On job profile, $57.8 \%$ work in government sectors, $23.7 \%$ work in private companies, $10.1 \%$ had their own business, and $8.4 \%$ were unemployed.

Before starting analysis, the normality and reliability of data is checked. The data is normally distributed and 30 responses were deleted because they were detected as outliers. Moreover, the data is free from Multicollinearity issues, because the correlation between any two variables is less than 0.90 (Tabacknik \& Fidell, 2001). Firstly, measurement model is drawn using Amos-18 to examine the appropriateness of the proposed mode using several fit indices. The chi square statistics (243.433) is significant in the sample $(p<0.01)$ and degree of freedom (df) is equal to 109. Other fit indices such as Goodness of Fit (GFI) is equal to 0.898, Adjusted Goodness of Fit (AGFI) is 0.861, Comparative Fit Index 
(CFI) estimate is 0.978 , Tucker Lewis Index (TLI) is equal to 0.974, and Root Mean Square error of Approximation (RMSEA) is equal to 0.067 . Based on these results, it can be concluded that the model fits the data well (Hair, Black, Babin, Anderson, \& Tatham, 2010).

Moreover, CFA analysis is carried out after achieving goodness of fit for the model. As shown in Table 1, the factor loadings of items for each construct are calculated. The results indicated that the standardized factor loadings of items ranged from 0.27 to 0.96 and are significant. Items with factors loadings that are less than 0.50 were eliminated. Therefore, convergent validity is supported. CFA analysis is done rather than exploratory factor analysis because the established measurement scale is used and validated in previous studies. But the validity and reliability of the scale were conducted for better verification of respondent's understanding, because the scale is being tested in different environment, and in different industry context.

Table 1. CFA Results

\begin{tabular}{|c|c|c|c|c|c|}
\hline Constructs & Items & Loadings & Cronbach's Alpha & Composite Reliability & AVE \\
\hline $\mathrm{COO}$ & $\begin{array}{l}\mathrm{COO1} \\
\mathrm{COO2} \\
\mathrm{COO} 3 \\
\mathrm{COO4} \\
\mathrm{COO5}\end{array}$ & $\begin{array}{l}0.890 \\
0.941 \\
0.948 \\
0.943 \\
0.934\end{array}$ & 0.970 & 0.975 & 0.863 \\
\hline Relationship Quality & $\begin{array}{c}\text { Trust } \\
\text { Commitment } \\
\text { Satisfaction }\end{array}$ & $\begin{array}{l}0.916 \\
0.798 \\
0.929\end{array}$ & 0.967 & 0.914 & 0.780 \\
\hline Brand Trust & $\begin{array}{l}\text { BT1 } \\
\text { BT2 } \\
\text { BT3 } \\
\text { BT4 }\end{array}$ & $\begin{array}{l}0.943 \\
0.964 \\
0.719 \\
0.851\end{array}$ & 0.927 & 0.928 & 0.765 \\
\hline Brand Commitment & $\begin{array}{l}\text { BC2 } \\
\text { BC3 } \\
\text { BC4 }\end{array}$ & $\begin{array}{l}0.820 \\
0.949 \\
0.932\end{array}$ & 0.925 & 0.929 & 0.814 \\
\hline Brand Satisfaction & $\begin{array}{l}\text { BS1 } \\
\text { BS2 } \\
\text { BS3 } \\
\text { BS4 } \\
\text { BS5 }\end{array}$ & $\begin{array}{l}0.949 \\
0.943 \\
0.957 \\
0.949 \\
0.933\end{array}$ & 0.977 & 0.977 & 0.895 \\
\hline
\end{tabular}

Moreover, to test the construct reliability, Cronbach's alpha and composite reliability for each variable were calculated. The results presented in Table 1 indicate that the Cronbach's alpha of all constructs is higher than the cut-off value of 0.70 as suggested by Hair et al. (2010); country of origin (0.954), brand trust (0.920), brand commitment (0.918), and brand satisfaction (0.967). It shows that all values range between 0.918 and 0.967 , thus providing good indication of internal consistency and reliability. Similarly, composite reliability ranges between 0.914 and 0.977 which provides further support for the reliability of measures (Hair et al., 2010). Additionally, discriminant validity of the construct was calculated using the shared average variance extracted between the pair of constructs, and the results show that the values ranged between 0.874 and 0.946 (Fornell and Larcker, 1981).

As stated above, in order to test the hypotheses, structural model was drawn. The results showed that the chisquare for goodness of fit is 253.335 and CMIN is equal to 2.203 with $115^{\circ}$ degree of freedom. Other fit indices are used to support the ch-square and CMIN. For example, GFI which indicates the amount of variance in the sample accounted for 0.894 is quite good. Moreover, AGFI has acceptable fit value of 0.859 ; TLI value is equal to 0.973 . In addition the value of CFI is equal to 0.977 , and RMSEA value is 0.069 , also fine. Overall, the results show that the model has a good fit for the data (Hair et al., 2010).

The research hypotheses were tested on the basis of standardized structural coefficients with SEM. The results depicted in Table 2 reveal that country of origin is significantly and positively related with brand trust $(\beta=0.581, C R=$ $12.945, p<0.05)$ and accounted for 46.6 percent of variance in brand trust, therefore $\mathrm{H} 1$ is supported. Similarly, the results demonstrated that country of origin has significant positive relationship with brand commitment $(\beta=0.523, C R=$ $10.881, p<0.05$ ) and accounted for 30 percent of variance in brand commitment, thus, $\mathrm{H} 2$ is supported. Moreover, the results indicated that country of origin has significant positive relationship with brand satisfaction $(\beta=0.605, C R=12.571$, 
$\mathrm{p}<0.05)$ and accounted for 30 percent of its overall variance, therefore $\mathrm{H} 3$ is supported. Finally, the results showed that that country of origin has significant positive relationship with overall relationship quality $(\beta=0.558, C R=12.601, p<0.05)$ and accounted for 51.2 percent of its variance, hence $\mathrm{H} 4$ is supported.

Table 2. Research Findings

\begin{tabular}{|c|c|c|c|c|c|c|}
\hline & Hypothesized Effect & $\begin{array}{c}\text { Std. } \\
\text { Estimate }\end{array}$ & S.E. & C.R. & $\mathbf{P}$ & Support \\
\hline H1: & Country of origin has positive effect on brand trust & 0.581 & 0.044 & 12.945 & $\star \star \star \star$ & Yes \\
\hline $\mathrm{H} 2$ : & Country of origin has positive effect on brand commitment & 0.523 & 0.048 & 10.881 & *** & Yes \\
\hline H3: & Country of origin has positive effect on brand satisfaction & 0.605 & 0.048 & 12.571 & *** & Yes \\
\hline H4: & Country of origin has positive effect on overall relationship quality & 0.558 & 0.044 & 12.601 & 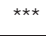 & Yes \\
\hline
\end{tabular}

***: $p<0.001 ; * *: p<0.01 ; *: p<0.05$

\section{Discussion}

The rationale of this study was to test the influence of country of origin image on relationship quality. Results showed that country of origin has a significant positive influence on overall relationship quality. Tam (2008) also considered country of origin as an important factor for evaluating brands and influencing customer relationships. Particularly, country-of-origin is associated with various marketing factors that affect customers' behaviour and help organizations to sustain valuable customer relationships (Michaelis et al., 2008; Tam, 2008). However, because relationship quality could be influenced by the power of country of origin image, it is suggested that practitioners should employ various incentives to improve perceived brands' reliability in global markets that engender long-term beneficial transactions with customers (Dahlstrom \& Nygaard, 1995; Morgan \& Hunt, 1994; Singh \& Sirdeshmukh, 2000).

Moreover, it is observed that country of origin image has significant positive effect on brand trust. As the image of a country increases, the perception about products originating from that country also enhances customers' trust. Certain scholars (Dehkordi et al., 2012; Jiménez \& San Martín, 2010; Rosenbloom \& Haefner, 2009) also revealed that country of origin image had a significant influence on brand trust. Besides, this study found out that country of origin has a significant positive influence on brand commitment. The relationship of country of origin with brand commitment is also significant with the literature (Pappu \& Quester, 2006; Yoo, Donthu, \& Lee, 2000). Consequently, the reputation of brands originating from a particular country turns to be an evaluation criterion for accessible offer and a cornerstone in creating trust-based relationships (Nijssen \& Herk, 2009).

Moreover, this study indicates that country of origin has significant positive impact on brand satisfaction. A greater support was seen in several previous studies (Arambewela \& Hall, 2006; Ayyildiz \& Cengiz, 2007; Jiménez \& San Martín, 2010; Stephen, 2009) who reported a significant effect of country of origin on brand satisfaction. Similarly, Vida and Reardon (2008) demonstrated that country of origin of a product may affect the initial perception of customers about a specific brand as it can create positive perception about new products and influences brand evaluation. Particularly, customer are anxious about country of origin when it comes to purchasing cars, because this type of product is associated with high cost and thus, they expect it to be of high-quality. For them to be satisfied about purchasing decision, they usually prefer to select brands originating from countries with favourable image.

In line with information processing theory, this study reveals that country of origin has significant poistive effect on relationship quality. Because the perception of customers towards a certain country image influences their evaluation of products coming from that country, this could affect their purchase intention and brand choice. This in turn would result in reinforcing the linkages between customers and a particular brand. Consequently, customer relationships with a brand are in most cases created after customers collect related information about that brand (Haefner, Deli-Gray, \& Rosenbloom, 2011). Thereby, the country of origin information leads to better brand familiarity and thus, enhanced customer brand relationships. Jiménez and Martín (2012) confirmed that country of origin information works as a safeguard transaction to establish successful brand relationships.

\section{Limitations and Future Research}

There are several limitations incurred in this study which would open opportunities for future researches. For example, the data was collected from respondents in one country (Malaysia). Some characteristics of the country may have an effect on the strength of relationships between country of origin image and relationship quality. Thus, replications of this 
study in other country contexts would be important. Besides, this study focuses on automotive sector, and the respondents were limited to those in northern region of Malaysia. Therefore, future researchers could take the opportunity to employ larger sample population to gain higher responses that would make the findings more reliable and valid. Also parallel studies in other product categories are other future opportunities for research. Future studies may also look into the possibilities of making comparison towards customers' perception on brands originating from different countries.

Besides, only country of origin was considered as antecedent of relationship quality. Therefore, future research may consider other factors such as after sale service and product innovation to test their effect on relationship quality. Particularly, based on the review of past studies, it shows that these variables have strong relevance to automotive product, but surprisingly scholars have somewhat paid less attention for these variables in context of brand relationship quality. Moreover, this study followed the quantitative approach through survey instrument for data collection; thus, future research may wish to use qualitative methodologies to gain better insights on the significant factors that influence relationship quality. Finally, this study is cross sectional in nature, future research may overcome this issue through longitudinal data.

\section{Conclusion}

This study examined the importance of country of origin in developing customer-brand relationships in Malaysian automotive market. Overall, it can be concluded that country image has significant positive effect on relationship quality. Moreover, country of origin plays an important role in engendering its elements; brand trust, brand commitment, and brand satisfaction. This means that brands originating from favourable country image could have better abilties to develop positive relationships with their customers. This study builds upon the literature by examining the relationship between the said variables as empirical evidence in this context is very limited. The findings also build upon information processing theory by providing further support for the positive effect of country of origin on relationship quality from Southeast Asian context; Malaysia.

This study has several practical implications. For example, the practitioners can utilize the findings in order to implement the relevant strategies to establish higher levels of customer relationships. The findings may also provide automotive managers with better understandings towards the role of country of origin in influencing the dimensions of relationship quality, which will further insist them to set more effective strategies to cope with challenging market environments. It is believed throught better customer relationships; organizations would have better capabilities to know about customer's behavior and requirements in order to meet such needs. The ability of a brand to develop such valuable relationships with customers could further facilitate its overall performance and strengthen the level of competitiveness to maintain strong in the presence of competing rivals.

\section{References}

Abdullah, M. F., Putit, L., \& Teo, C. B. C. (2014). Impact of Relationship Marketing Tactics (RMT's) \& Relationship Quality on Customer Loyalty: A Study within the Malaysian Mobile Telecommunication Industry. Procedia-Social and Behavioral Sciences, $130,371-$ 378.

Ali, S. H. S. (2010). Scaling for better service performance: effects of respect and rapport on relationship quality in Malaysia. Interdisciplinary Journal of Research in Business, 1(8), 72-82.

Anderson, E.W., Fornell, C., \& Lehmann, D.R. (1994). Customer satisfaction, market share and profitability. Journal of Marketing, 58(3), 53-66.

Anderson, E. W., Weitz, B. (1992). The Use of Pledges to Build and Sustain Commitment in Distribution Channels. Journal of Marketing Research, 29(February), 18-34.

Anderson, J.C., \& Narus, J.A. (1990). A Model of Distributor Firm and Manufacturer Firm Working Partnerships. Journal of Marketing, 54, 42-58.

Arambewela, R., \& Hall, J. (2006). A comparative analysis of international education satisfaction using SERVQUAL. Journal of Services Research, 6, 141-163.

Ayyildiz, H., \& Cengiz, E. (2007). country image effect on customer loyalty model. Innovative Marketing, 3(2), 44-64.

Barry, J.M., Dion, P., \& Johnson, W. (2008). A cross-cultural examination of relationship strength in B2B services. Journal of Services Marketing, 22(2), 114-135.

Bennett, R., \& Gabriel, H. (2001). Reputation, trust and supplier commitment: The case of shipping company/seaport relations. The Journal of Business and Industrial Marketing, 16(6/7), 424-438.

Bennet, R., \& Rundle-Thiele, S. (2004). Customer satisfaction should not be the only goal. Journal of Service Marketing, 18(7), 514-523.

Chin, W. W. (1998). Issues and opinion on structural equation modeling. MIS Quarterly, 22(1), 7-16.

Chisik, R. (2003). Export industry policy and reputational comparative advantage. Journal of International Economics, 59(2), $423-451$. 
Chung, K. H., \& Shin, J-I. (2010). The antecedents and consequents of relationship quality in internet shopping. Asia Pacific Journal of Marketing and Logistics, 22(4), 473-491.

Creswell, J. W. (2012). Educational research: Planning, conducting, and evaluating quantitative and qualitative research, 4th ed. Boston: Pearson.

Crosby, L. A., Evans, K.R., \& Cowles, D. (1990). Relationship quality in services selling: An interpersonal influence perspectives. Journal of Marketing, 54, 68-81.

Dahlstrom, R., \& Nygaard, A. (1995). An Exploratory Investigation of Interpersonal Trust in New and Mature Market Economies. Journal of Retailing, 71, 339-361.

De Wulf, G., Odeken-Schroder \& lacabucci, D. (2001). Investment in consumer relationship: A cross country and cross industry exploration. Journal of Marketing, 65(Oct), 33-50.

Doney, P. M., \& Cannon, J. P. (1997). An examination of the nature of trust in buyer-seller relationships. Journal of Marketing, 61(2), 3551.

Dorsch, M. J., Swanson, S.R., \& Kelley, S.W. (1998). The role of relationship quality in the stratification of vendors as perceived by customers. Journal of Academy Marketing Science, 26, 128-142.

Dwyer, F. R., Schurr, P.H., \& Oh, S. (1987). Developing buyer-seller relationships. Journal of Marketing, 51(4), 11-27.

Essoussi, L. H., \& Merunka, D. (2007). Consumers' product evaluations in emerging markets: Does country of design, country of manufacture, or brand image matter? International Marketing Review, 24(4), 409-426.

Ford, D. (1980). The development of buyer-seller relationships in industrial markets. European journal of marketing, 14(5/6), 339-353.

Fornell, C., \& Larcker, D. F. (1981). Evaluating structural equation models with unobservable variables and measurement error. Journal of Marketing Research, 18(1), 39-50.

Garbarino, E., \& Johnson, M. S. (1999). The different roles of satisfaction, trust and commitment in customer relationships. Journal of Marketing, 63(2), 70-87.

Ganesan, S. (1994). Determinants of long-term orientation in buyer-seller relationships. Journal of Marketing, 58(2), 1-19.

Gounaris, S.P. (2005). Trust and commitment influences on customer retention: Insights from business-to-business services. Journal of Business Research, 58(2), 126-140.

Gunzler, D., Chen, T., Wu, P., \& Zhang, H. (2013). Introduction to mediation analysis with structural equation modeling. Shanghai Archives of Psychiatry, 25(6), 390-394.

Hair, J. F., Jr., Black, W. C., Babin, B. J., Anderson, R. E., \& Tatham, R. L. (2010). Multivariate Data Analyisis (7th ed.) Upper Saddle River, N.J: Pearson Prentice Hall.

Halimi, A.B., Chavosh, A., \& Choshali, S.H. (2011). The Influence of Relationship Marketing Tactics on Customer's Loyalty in B2C Relationship - the Role of Communication and Personalization.European Journal of Economics, Finance and Administrative Sciences, (31), 50-56.

Hennig-Thurau, T., \& Klee, A. (1997). The Impact of Customer Satisfaction and Relationship Quality on Customer Retention: A Critical Reassessment and Model Development. Psychology \& Marketing, 14(8), 37-765

Hennig-Thurau, T., Langer, M.K., \& Hansen, U. (2001). Modeling and Managing Student Loyalty: An Approach Based on the Concept of Relationship Quality. Journal of Service Research, 3(4), 331-44.

Hibbard, J. D., Kumar, N., \& Stern, L. W. (2001). Examining the impact of destructive acts in marketing channel relationships. Journal of Marketing Research, 38(1), 45-61.

Hilman, H., Abd-Ghani, N. H., \& Hanaysha, J. (2013). Relationship Quality as a Strategic Tool in Today's Turbulent Business. Australian Journal of Basic and Applied Sciences, 7(14), 478-787.

Hoe, S. L. (2008). Issues and procedures in adopting structural equation modeling technique. Journal of Applied quantitative methods, 3(1), 76-83.

Hsu, F-M., Chen. T-Y., \& Huang, T-Y. (2007). The effects on the relationship learning form relationship enhancement activities. Journal of Relationship Marketing, 6(1), 89-107.

Huang, H. H., \& Chiu, C. K. (2006). Exploring customer satisfaction, trust and destination loyalty in tourism. Journal of American Academy of Business, 10(1), 156-159.

Ibrahim, H., \& Najjar, F. (2008). Relationship bonding tactics, personality traits, relationship quality and customer loyalty: behavioral sequence in retail environment. ICFAI Journal of Services Marketing, 6(4), 6-37.

Ivens, B. S., \& Pardo, C. (2007). Are key account relationships different? Empirical results on supplier strategies and customer reactions. Industrial Marketing Management, 36(4), 470-82.

Jiménez, N. H., \& San Martín, S. (2010). The role of country-of-origin, ethnocentrism and animosity in promoting consumer trust. The moderating role of familiarity. International Business Review, 19(1), 34-45.

Jiménez, N., \& Martín, S. S. (2012). Emerging Markets Commerce: The Role of Country-of Origin and Animosity in Purchase Intention. International Journal of Business and Management, 7(17), 34-42.

Kari, F., and Rasiah, R. (2008), Automobile Emissions and the Environment: The Malaysian Policy Response, Making Choices about Hydrogen: Transport Issues for Developing Econonomies, Tokyo: United Nations University.

Kim, C.K. (1995). Brand popularity and country image in global competition: managerial implications. Journal of Product \& Brand Management, 4(5), p.222-33.

Krejcie, R. V., \& Morgan, D. W. (1970). Determining sample size for research activities, Educational and Psychological Measurement, $30,607-610$. 
Lei, M., \& Lomax, R. G. (2005). The Effect of Varying Degrees of Nonnormality in Structural Equation Modeling. Structural Equation Modeling, 12(1), 1-27.

Lemon, K.N., Rust, R.T., \& Zeithaml, V.A. (2001). What Drives Customer Equity. Marketing Management, 10(1), $20-25$.

Lin, L. Y., \& Chen, C. S. (2006). The influence of the country-of-origin image, product knowledge and product involvement on consumer purchase decisions: an empirical study of insurance and catering services in Taiwan. Journal of Consumer Marketing, 23(5), 248265.

Michaelis, M., Woisetschläger, D. M., Backhaus, C., \& Ahlert, D. (2008). The effects of country of origin and corporate reputation on initial trust: An experimental evaluation of the perception of Polish consumers. International Marketing Review, 25(4), 404-422.

Mohammad, A. A. S. (2012). The Effect of Brand Trust and Perceived Value in Building Brand Loyalty. International Research Journal of Finance and Economics, 85, 111-126.

Moorman, C., Deshpandé, R., \& Zaltman, G. (1993). Factors affecting trust in market research relationships. Journal of Marketing, 57(1), 81-101.

Morgan R., \& Hunt, S. D. (1994). The commitment-trust theory of relationship marketing. Journal of Marketing, 58(3), 20-38.

Mukherjee, A., \& Nath, P. (2007). Role of electronic trust in online retailing: a re-examination of the commitment-trust theory. European Journal of Marketing, 41(9/10), 1173-202.

Ndubisi, N. O. (2007). Relationship quality antecedents: The Malaysian retail banking perspective. International Journal of Quality \& Reliability Management, 24(8), 829-845.

Nijssen, E. J. \& Herk, H. V. (2009). Conjoining International Marketing and Relationship Marketing: Exploring Consumers' CrossBorder Service Relationships. Journal of International Marketing, 17(1), 91-115.

O'Cass, A., \& Grace, D. (2003). An exploratory perspective of service brand associations. The Journal of Services Marketing, 17(4/5), $452-475$.

Ok, C., Choi, Y. G., \& Hyun, S. S. (2011). Roles of Brand Value Perception in the Development of Brand Credibility and Brand Prestige. Paper presented at the International CHRIE Conference-Refereed Track, Event, United States.

Pappu, R., \& Quester, P. (2006). Does customer satisfaction lead to improved brand equity? An empirical examination of two categories of retail brands. Journal of Product \& Brand Management, 15(1), 4-14.

Pappu, R., Quester, P.G. \& Cooksey, R.W. (2006). Consumer-based brand equity and country-of-origin relationships: Some empirical evidence. European Journal of Marketing, 40(5/6), p.696-717.

Paswan, A.K., Kulkarni, S. \& Ganesh, G. (2003). Loyalty towards the country, the state and the service brands. The Journal of Brand Management, 10(3), p.233-251.

Piron, F. (2000). Consumers perceptions of country of origin effet on purchasing intentions of conspicuous products. Journal of Consumer Marketing, 308-321.

Rauyruen, P. \& Miller, K.E. (2007). Relationship quality as a predictor of B2B customer loyalty. Journal of Business Research, 60, 21-31.

Rezvani, S., Shenyari, G., Dehkordi, G. J., Salehi, M., Nahid, N., \& Soleimani, S. (2012). Country of Origin: A Study over Perspective of Intrinsic and Extrinsic Cues on Consumers ' Purchase Decision. Business Management Dynamics, 1(11), 68-75.

Roberts, K., Varki, S., \& Brodie, R. (2003). Measuring the Quality of Relationships in Consumer Services: An Empirical Study. European Journal of Marketing, 37(1/2), 169-96.

Roberts-Lombard, M. (2009). Customer retention strategies implemented by fast-food outlets in the Gauteng, Western Cape and KwaZulu-Natal provinces of South Africa: a focus on Something Fishy, Nando's and Steers. African Journal of Marketing Management, 1(2), 70-80.

Rosenbloom, A., \& Haefner, J. E. (2009). Country-of-Origin Effects and Global Brand Trust: A First Look. Journal of Global Marketing, 22, 267-278.

Roth, M.S., \& Romeo, S. B. (1992). Matching Product Category and Country Image Perceptions: A Framework for Managing Country-oforigin Effects. Journal of International Business Studies, 23, 477-497.

Sanyal, S. N., \& Datta, S. K. (2011). The effect of country of origin on brand equity: an empirical study on generic drugs. Journal of Product \& Brand Management, 20(2), 130-140.

Saydan, R. (2013). Relationship between Country of Origin Image and Brand Equity: An Empirical Evidence in England Market. International Journal of Business and Social Science, 4(3), 78-88.

Schultz, D. E. (2005). The loyalty paradox. Marketing Management, 14(5), 10-11.

Sean, D. B., Brian. F., \& Evelyn, R. (2004). Evaluating Relationship Quality in Business-to-Business Context. Irish Journal of Management, 25(2), 61.

Singh, J. \& Sirdeshmukh, D. (2000). Agency and Trust Mechanisms in Consumer Satisfaction and Loyalty Judgments. Journal of the Academy of Marketing Science, 28(1), 150-167.

Spreng, R.A., Mackenzie, S.B., \& Olshavsky, R.W. (1996). A reexamination of the determinants of consumer satisfaction. Journal of Marketing, 60(3), 15-32.

Steenkamp, J.-B.E.M., \& Geyskens, E. (2006). How country characteristics affect the perceived value of web sites. American Marketing Association, 70, 136-150.

Stephen, L. S. J.R, (2009). Brand image, satisfaction, and loyalty among malaysian female consumers: The Moderating Effects of Personality and Dwelling Area. Unpublished PhD thesis, Universiti Sains Malaysia.

Tabachnick, B. G., \& Fidell, L. S. (2001). Using multivariate statistics. 4th ed. Needham Heights, MA: Allyn \& Bacon.

Tam, J. L. M. (2008). Brand familiarity: its effects on satisfaction evaluations. Journal of Services Marketing, 22(1), 3-12. 
Taylor, T. B. (1998). Better loyalty measurement leads to business solutions. Marketing News, 32(22), 41.

Ulaga, W., \& Eggert, A. (2006). Relationship value and relationship quality: Broadening the nomological network of business-to-business relationships. European Journal of Marketing, 40(3/4), 311-327.

Ural, T. (2007). The antecedents and consequences of relationship quality according to stages of the relationship between exporters and importers.Problems and Perspectives in Management, 5(3), 111-138.

Walter, A., Muller, T., Helfert, G., \& Ritter, T. (2003). Functions of industrial supplier relationships and their impact on relationship quality. Industrial Marketing Management, 32(1), 159-69.

Wong, A., \& Sohal, A. (2002). An examination of the relationship between trust, commitment and relationship quality. International Journal of Retail \& Distribution Management, 30(1), 34-50.

Van Vuuren, T., Roberts-Lombard, M., \& Van Tonder, E. (2013). Customer satisfaction, trust and commitment as predictors of customer loyalty within an optometric practice environment. Southern African Business Review, 16(3), 81-96.

Vida, I. \& Reardon, J. (2008). Domestic consumption: rational, affective or normative choice? Journal of Consumer Marketing, 25(1), 3444.

Vieira, A. L., Winklhofer, H., \& Ennew, C. T. (2008). Relationship Quality: a literature review and research agenda. Journal of Customer Behaviour, 7(4), 269-291.

Yoo, B., Donthu, N. \& Lee, S. (2000). An examination of selected marketing mix elements and brand equity. Academy of Marketing Science, 28(2), 195-212.

Zboja, J. J., Voorhees, C. M. (2006). The impact of brand trust and satisfaction on retailer repurchase intentions. Journal of Services Marketing, 20(6), 381-390.

Zhang, X., \& Feng, Y. (2009). The Impact of Customer Relationship Tactics on Customer Loyalty - Within Swedish Mobile Telecommunication Industry. Master Thesis of Halmstad University.

Appendix A: Measurement Scale of Constructs

\begin{tabular}{|c|c|}
\hline Relationship Quality Dimesnions & Factor Loadings \\
\hline \multicolumn{2}{|l|}{ a. $\quad$ Brand Satisfaction ( $\alpha=0.977)$} \\
\hline I am satisfied with my decision to purchase this car. & 0.949 \\
\hline My choice to buy this car was a wise one. & 0.943 \\
\hline I think that I did the right thing when I bought this car. & 0.957 \\
\hline I am happy that I bought this car. & 0.949 \\
\hline I truly enjoyed the purchase of this car. & 0.933 \\
\hline \multicolumn{2}{|l|}{ b. $\quad$ Brand Trust $(\alpha=0.927)$} \\
\hline The car brand I'm using is trustworthy & 0.943 \\
\hline The car l'm using is reliable. & 0.964 \\
\hline The car l'm using is being delivered on time. & 0.719 \\
\hline The car l'm using is safe. & 0.851 \\
\hline \multicolumn{2}{|l|}{ c. Brand Commitment $(\alpha=0.925)$} \\
\hline I am willing to make small sacrifices in order to keep using this car brand. & 0.820 \\
\hline I have made a pledge to stick with this car brand & 0.949 \\
\hline I will stay with this car brand through good and bad times & 0.932 \\
\hline \multicolumn{2}{|l|}{ Country of Origin ( $\alpha=0.970)$} \\
\hline This car brand originated from a country high in R\&D compared to other brands. & 0.890 \\
\hline $\begin{array}{l}\text { This car brand originated from a country with a high level of technological advancement compared to other } \\
\text { brands. }\end{array}$ & 0.941 \\
\hline This car brand originated from a country which maintains a high level of quality compared to other brands. & 0.948 \\
\hline $\begin{array}{l}\text { This car brand originated from a country which maintains an image of continuous car development } \\
\text { compared to other brands. }\end{array}$ & 0.943 \\
\hline $\begin{array}{l}\text { This brand originated from a country which is prestigious in terms of car manufacturing compared to other } \\
\text { brands. }\end{array}$ & 0.934 \\
\hline
\end{tabular}

